\title{
On the Cover
}

Portions of the following are based on interviews with Eliza Rathbone, chief curator of the Phillips Collection in Washington, DC, on June 18, 2009, and Susan Vreeland, author of Luncheon of the Boating Party (Viking, 2007), on June 23, 2009.

This issue of the American Psychologist honors awardwinning psychologists recognized for their outstanding achievements; for many awardees, this award represents the apex of a long career. The well-known painting on the cover, Luncheon of the Boating Party, represents a major event in art history and epitomizes the artist's extraordinary skills in portraiture, landscape, and still life. Pierre-Auguste Renoir (1841-1919) set out to make a major statement, an ambitious goal that he accomplished with this masterpiece. According to Phillips Collection curator Eliza Rathbone, "To this day some would say it is his greatest work."

The American Psychological Association awards are a celebration of work well done. Renoir's painting is also a celebration. It celebrates the joie de vivre that was returning to Paris after two crushing conflicts: the Paris Commune and subsequent massacre and the Franco-Prussian War. It celebrates a century drawing to a close, and it celebrates happy days with friends. Renoir was at the peak of his abilities when he began the painting in the late summer of 1880, and he completed it early in 1881. He was a master of both impressionism and classical style and had developed a unique blending of the two. An impressionist landscape forms the background for the gathering of a group of Renoir's friends. The 13 portraits, although classical in appearance and style, reveal the brush strokes and use of color of the Impressionists. The still life of the table with its bottles, glasses, tablecloth, and food, has-like the portraits-both classical and impressionist elements: The composition is classical, but the execution is in the impressionist mode. The still life shows the quality of his brushwork and his technical mastery. His execution of the reflected light in the bottles and glasses gives the viewer a sense of being out of doors.

The people in the painting come from various walks of life. The elegant editor Charles Ephrussi, in a top hat, is having a conversation with a young poet, Jules LaForgue, his part-time secretary. The man and woman leaning against the railing of La Maison Fournaise are the son and daughter of the proprietor. Two of the women in the painting were connected to the theatre: the woman sipping wine (Ellen Andrée) and the woman with her hands to her ears (Jeanne Samary). The woman at the front right, known as Angèle, was a model. Aline Charigot at the front left became Renoir's wife. The painting also includes a war hero, an artist, an art collector and critic, and an Italian journalist. Counting the number of people in the painting, one finds a 14th person interacting with Andrée. All the people in the painting have been thoroughly researched and identified by the Phillips Collection, but it is not clear who this person is- he might be Renoir himself. Author Susan Vreeland noticed that there seem to be five conversations going on in the painting, which she used as a prompt in her novel, speculating on what the participants might be saying on the basis of her research into who they were and what was happening at that time in their lives. Although it is not really necessary to know this underlying narrative to enjoy the painting, it enriches the experience and allows one to go below the surface.

The portraits were perhaps Renoir's greatest challenge: Not all the models could pose at each session. Note that the white shirts of the two bare-armed men plus the tablecloth form a white "cup" that holds the group steady despite the fact that one knows the people must have been moving about and were still for only a moment.

Duncan Phillips, whose personal collection formed the core of the Phillips Gallery, recognized the charismatic appeal of the painting and bought it in 1923 for his recently opened (1921) gallery. He knew it would be a magnet and bring people in from far away. Rathbone said it was clear that this masterpiece of French painting needed to be in a public place, and it still enraptures viewers. According to Rathbone, what draws viewers in again and again is the fact that "each model is based on a real human being; each has individuality and reflects who they were." She finds the subject matter beguiling: "Each brush stroke captured so much-the subject matter, color, liveliness-attractive people having a good time."

Renoir came from a humble background. His mother was a seamstress, his father a tailor. Renoir was comfortable throughout his life with the working class. He could also interact smoothly with the upper echelons of society, as they were the ones who collected his paintings and commissioned portraits. Renoir had a happy disposition to which people responded. Social constraints were loosening in France at this time, and Renoir epitomized this new order. According to Vreeland, Renoir loved four things: light, color, women, and the sensuality of paint. Luncheon of the Boating Party contains all four. Perhaps one of the most amazing facts about this painting is that Renoir created such spatial and configurational sense without sketches or studies. It was a virtuoso performance. It is rumored that on the last day of his life, Renoir was painting flowers and said in effect, "I think I am beginning to catch on."

Sandra M. Fowler Art Co-Editor 